\title{
Faktor-Faktor yang Mempengaruhi Keputusan Pembelian di Warung Ikan Bakar Kabupeten Situbondo
}

\author{
Nandita Aurelia Nilakandy ${ }^{1 *}$, Wenny Dhamayanthi ${ }^{1}$, Ratih Puspitorini Yekti Ambarkahi ${ }^{1}$, \\ Andi Muhammad Ismail ${ }^{1}$ \\ ${ }^{1}$ Department of Agribusiness Management, Politeknik Negeri Jember \\ *nanditaaurelia01@gmail.com
}

Submitted: 08 Feb 2021

Accepted: 14 May 2021

Published: 28 Jun 2021

\begin{abstract}
ABSTRAK
Penelitian ini bertujuan untuk menganalisis dan menguji pengaruh kualitas produk, harga, kualitas layanan dan lokasi terhadap keputusan pembelian di warung ikan bakar Bu Tatik Kabupaten Situbondo. Metode penelitian ini menggunakan metode penelitian survei. Teknik analisis data yang digunakan adalah Analisis Regresi Linier Berganda dengan menggunakan program SPSS 21.00 for windows. Hasil pengujian menunjukkan bahwa variabel kualitas produk, harga, kualitas layanan dan lokasi secara serempak berpengaruh signifikan terhadap keputusan pembelian. Pengujian regresi secara parsial kualitas produk, harga kualitas layanan dan lokasi berpengaruh signifikan terhadap keputusan pembelian dan variabel berpengaruh dominan adalah kualitas produk.
\end{abstract}

Kata kunci: Kualitas produk, Harga, Kualitas Layanan, Lokasi dan Keputusan Pembelian

\section{ABSTRACT}

This study aims to analyze and examine the influence of product quality, price, service quality and location on purchase decision in Bu Tatik grilled fish stall Situbondo Regency. This research method uses survey research methods. The data analysis technique used is Multiple Linear Regression Analysis using SPSS 21.00 for windows program. The test results show that the variables of product quality, price, service quality and location simultaneously have a significant effect on purchasing decisions. Partial regression testing of product quality, price of service quality and location have a significant effect on purchasing decisions and the dominant influencing variable is product quality.

Keyword: Product Quality, Price, Service Quality, Location and Purchasing Decision

\section{Pendahuluan}

Perkembangan ekonomi begitu pesat seiring dengan persaingan dalam dunia bisnis yang semakin meningkat terutama pada bisnis kuliner. Hal ini menyebabkan perusahaan harus memperhatikan keinginan dan kebutuhan konsumen sehingga dapat memunculkan suatu tindakan perilaku konsumen. Perilaku konsumen merupakan tindakan atau perilaku yang dilakukan konsumen yang dimulai dengan merasakan adanya kebutuhan dan keinginan, berusaha mendapatkan produk yang diinginkan, mengkonsumsi produk tersebut dan berakhir dengan tindakan pascapembelian yaitu memiliki perasaan puas atau tidak puas serta mampu meyakinkan konsumen untuk memutuskan pembelian sesuai dengan kualitas produk yang dihasilkan[1]. Kualitas produk merupakan suatu hasil olahan yang ditawarkan penjual dengan mempunyai nilai jual yang tidak dimiliki produk pesaing, sehingga segala sesuatu yang ditawarkan ke pasar yang bertujuan untuk mendapatkan perhatian, dibeli, digunakan atau dikonsumsi yang dapat memuaskan kebutuhan[2]. Harga sangat penting dalam pengambilan keputusan pembelian karena harga yang mampu bersaing dipasaran akan menumbuhkan suatu keinginanan untuk melakukan suatu pembelian. Selain itu, persepsi konsumen juga dipengaruhi oleh kualitas 
layanan yang menjadi tolak ukur pada suatu pengambilan keputusan pembelian sehingga konsumen dapat menilai kinerja dan merasakan kepuasan atas kualitas pelayanan yang disediakan. Lokasi juga merupakan salah satu aspek penting yang dapat mempengaruhi bisnis dalam mengembangkan usaha. Salah satu bisnis usaha yang memenuhi beberapa aspek tersebut didaerah Kabupaten Situbondo adalah warung ikan bakar Bu Tatik. Warung ikan bakar Bu Tatik sudah berdiri sejak tahun 2014 tepatnya di Jl. Curahsale Satu, Sletreng, Kecamatan Kapongan, Kabupaten Situbondo. Warung ikan bakar Bu Tatik memiliki lokasi strategis tepatnya didaerah pesisir tambak dengan suasana warung makan di kelilingi persawahan. Menu yang ditawarkan warung ini juga tidak kalah menarik diantaranya ikan bakar, sop ikan laut, asam manis ikan laut, udang goreng, cumi goreng dan rajungan asam manis. Bahkan, warung ikan bakar Bu Tatik ini cukup terkenal dengan menu ikan bakar. Ikan yang akan dikonsumsi dapat dipilih secara langsung oleh konsumen dalam keadaan kondisi ikan masih segar. Namun dalam kegiatan usaha yang dilakukan terdapat beberapa kendala seperti semakin banyak persaingan bisnis yang mengakibatkan warung ini mengalami kenaikan dan penurunan penjualan. Bedasarkan hal tersebut dapat dijadikan suatu bahan penelitian yang menarik untuk diteliti. Tujuan dari penelitian ini yaitu untuk menganalisis dan menguji pengaruh kualitas produk, harga, kualitas layanan dan lokasi secara serempak terhadap keputusan pembelian, serta menganalisis dan menguji pengaruh kualitas produk, harga, kualitas layanan dan lokasi secara parsial terhadap keputusan pembelian, dan menganalisis dan menguji variabel kualitas produk, harga, kualitas layanan dan lokasi yang berpengaruh dominan terhadap keputusan pembelian.

\section{Metode Penelitian}

Penelitian ini bertujuan untuk mengetahui pengaruh kualitas produk, harga, kualitas layanan dan lokasi terhadap keputusan pembelian di warung ikan bakar $\mathrm{Bu}$ Tatik Kabupaten Situbondo. Metode penelitian ini adalah penelitian survey dengan metode pengumpulan data dalam penelitian yang terdiri dari observasi, wawancara dan kuesioner. Uji instrumen data yang digunakan dalam penelitian ini yaitu uji validitas dan uji reliabilitas. Metode analisis data yang digunakan dalam penelitian ini adalah analisis regresi linier berganda, analisis koefisien determinasi, uji $\mathrm{F}$ dan uji $\mathrm{t}$ dengan menggunakan alat bantu program SPSS 21.00 for windows.

Populasi dalam penelitian ini adalah seluruh konsumen yang melakukan pembelian atau telah membeli (baik dibungkus atau dimakan ditempat) di warung ikan bakar $\mathrm{Bu}$ Tatik Kabupaten Situbondo. Sampel dalam penelitian ini sebanyak 50 responden dengan teknik pengampilan sampel menggunakan analisis dengan multivarate, maka jumlah anggota sampel minimal 10 kali dari jumlah regresi variabel yang diteliti.

Penelitian ini menggunakan 5 variabel (4 variabel independen +1 variabel dependen), maka jumlah anggota sampel adalah $=10 \times 5=$ 50 responden.

\section{Hasil dan Pembahasan}

Warung ikan bakar Bu Tatik Kabupaten Situbondo menyajikan ikan bakar dengan bumbu yang melimpah dengan rasanya yang tidak pernah berubah, serta selalu menjaga kebersihan agar konsumen tetap merasakan kenyamanan pada saat melakukan pembelian atau mengkonsumsi secara langsung. Sehingga jika suatu kebutugan dapat terpenuhi dengan baik maka akan menciptakan suatu keputusan pembelian dan cenderung melakukan pembelian ulang

Sesuai hasil penelitian diketahui bahwa 50 responden dapat dilihat pada jenis kelamin didominasi yaitu jenis kelamin perempuan dengan perbandingan sebesar 27 responden perempuan dan 23 responden laki-laki. Dengan rentang usia 17-22 yaitu laki-laki 4 orang dan perempuan 2 orang. Pada rentang usia 23-28 yaitu laki-laki 4 orang dan perempuan 6 orang. Pada rentang usia 29-34 yaitu laki-laki 3 orang dan perempuan 3 orang. Pada rentang usia 35-40 yaitu laki-laki 4 orang dan perempuan 5 orang. Pada rentang usia 41-46 yaitu laki-laki 6 orang dan perempuan 10 orang. Pada rentang usia 4752 yaitu laki-laki 2 orang dan perempuan 1 orang. Sehingga dari hasil perolehan mengenai 
rentang usi juga didominasi pada jenis kelamin perempuan dengan presentase $54 \%$ dan laki-laki $46 \%$.

Uji instrumen dalam penelitian ini yaitu terdapat dua pengujian, diantaranya adalah uji validitas dan uji reliabilitas. Sedangkan analisis data yang digunakan diantaranya adalah analisis regresi linear berganda, analisis koefisien determinasi, uji $\mathrm{F}$, dan uji t. Adapun hasil pengujian dari uji instrumen dan analisis data tersebut ialah sebagai berikut:

\subsection{Uji Validitas,}

Pengujian validitas yang digunakan dalam penelitian ini adalah untuk menentuan item valid maupun tidak valid dapat dilihat pada nilai signifikan. Apabila nilai signifika $<0,05$ dapat diakatakan valid, tetapi sebaliknya jika nilai signifikan $>0,05$ item dinyatakan tidak valid [4]

\subsection{Uji Reliabilitas,}

pengujian dilakukan dalam uji reliabilitas ini adalah metode Cronbach's Alpha. Pada uji reliabilitas akan menunjukkan hubungan antara jumlah butir pertanyaan dengan relibilitas instrument. Hasil uji reliabilitas dikatakan reliabel apabila hasil perhitungan memiliki nilai reliabilitas sebesar $\alpha \geq 0,60$. Nilai Cronbach's Alpha dari kuesioner kualitas produk, harga, kualitas layanan dan lokasi yaitu sebesar 0,860 lebih besar dari angka kritis, sehingga dapat diartikan bahwa hasil kuesioner tersebut dapat dikatakan reliabel.

\subsection{Analisis regresi linier berganda}

Analisis data penelitian ini menggunakan analisis regresi linier berganda. Pada analisis regresi linier bergandadigunakan untuk mengetahui pengaruh antara variabel kualitas produk (X1), harga (X2), kualitas layanan (X3) dan lokasi (X4) terhadap keputusan pembelian (Y). Penelitian ini dilakukan analisis regresi linier berganda dengan alat bantu program SPSS 21.00 for windows.
Table 1. Hasil Analisisi Regresi Linier Berganda

\begin{tabular}{|c|c|c|c|c|c|c|}
\hline \multicolumn{7}{|c|}{ Coefficients $^{\mathbf{a}}$} \\
\hline & \multirow{2}{*}{ Model } & \multicolumn{2}{|c|}{$\begin{array}{c}\text { Unstandardized } \\
\text { Coefficients }\end{array}$} & \multirow{2}{*}{$\begin{array}{c}\begin{array}{c}\text { Standardized } \\
\text { Coefficients }\end{array} \\
\text { Beta }\end{array}$} & \multirow{2}{*}{$\mathrm{t}$} & \multirow{2}{*}{ Sig. } \\
\hline & & B & $\begin{array}{c}\text { Std. } \\
\text { Error }\end{array}$ & & & \\
\hline & (Constant) & 2,029 & 2,318 & &, 875 &, 386 \\
\hline & Total X1 & ,269 &, 085 &, 348 & 3,161 &, 003 \\
\hline \multirow[t]{3}{*}{1} & Total X2 & .322 &, 153 &, 182 & 2,100 &, 041 \\
\hline & Total $\times 3$ & ,266 & ,096 &, 312 & 2,782 &, 008 \\
\hline & Total X4 & .292 &, 134 &, 285 & 2,184 &, 034 \\
\hline
\end{tabular}

Berdasarkan tabel 1 dengan menggunakan alat bantu program SPSS 21.00 for windows diketahui bahwa persamaan regresi linier berganda sebagai berikut:

$Y=2,029+0,269 X 1+0,322 X 2+0,266 X 3+0,292 X 4+e$

Berikut penjelasan persamaan regresi linier berganda diinterpretasi sebagai berikut:

a. Nilai Konstanta (a) bernilai positif sebesar 2,029 menunjukkan bahwa apabila tidak ada variabel Kualitas Produk (X1), Harga (X2), Kualitas Layanan (X3), Lokasi (X4), maka nilai Keputusan Pembelian (Y) sebesar 2,029.

b. Nilai koefisien kualitas produk (X1) bernilai positif sebesar 0,269 menunjukkan apabila setiap bertambahnya kualitas produk (X1) sebesar 1 satuan, maka dapat meningkatkan keputusan pembelian (Y) sebesar 0,269. Jadi semakin baik kualitas produk yang diberikan maka dapat meningkatkan keputusan pembelian warung ikan bakar $\mathrm{Bu}$ Tatik di Kabupaten Situbondo.

c. Nilai Koefisien harga (X2) bernilai positif sebesar 0,322 menunjukkan apabila setiap bertambahnya harga (X2) sebesar 1 satuan, maka dapat meningkatkan keputusan pembelian (Y) sebesar 0,322. Maka dapat diartikan apabila semakin meningkatnya harga di warung ikan bakar Bu Tatik, maka dapat meningkatkan suatu keputusan pembelian, diimbangi dengan kualitas produk baik. Sehingga harga dapat bersaing dengan produk sejenisnya. Hal tersebut dapat meningkatkan keputusan pembelian walaupun harga di warung ikan bakar $\mathrm{Bu}$ Tatik meningkat setiap 1 level. 
d. Nilai koefisien kualitas layanan (X3) bernilai positif sebesar 0,266 menunjukkan apabila setiap bertambahnya kualitas layanan (X3) sebesar 1 satuan, maka dapat meningkatkan keputusan pembelian (Y) sebesar 0,266. Apabila pelayanan yang diberikan seperti fasilitas yang sediakan lengkap, pelayanan yang cepat, karyawan yang sopan dan ramah dalam penyajian dapat meningkatkan keputusan pembelian di warung ikan bakar $\mathrm{Bu}$ Tatik Kabupaten Situbondo.

e. Nilai koefisien lokasi (X4) bernilai positif sebesar 0,292 menunjukkan apabila setiap bertambahnya lokasi (X4) sebesar 1 satuan. Maka dapat meningkatkan keputusan pembelian (Y) sebesar 0,292. Lokasi yang mudah dijangkau dengan suasana yang nyaman. Hal ini meningkatkan keputusan pembelian di warung ikan bakar Bu Tatik Kabupaten Situbondo.

\subsection{Analisis koefisien determinasi (Adjusted $R^{2}$,}

Analisis ini dilakukan untuk mengetahui seberapa besar pengaruh variabel bebas yaitu Kualitas Produk (X1), Harga (X2), Kualitas Layanan (X3) Dan Lokasi (X4) terhadap variabel terikat yaitu keputusan pembelian (Y). Perhitungan dengan menggunakan alat bantu program SPSS 21.00 for windows.

Table 2. Hasil Analisis Koefisien Determinasi (Adjusted $\left.R^{2}\right)$

\section{Model Summary}

\begin{tabular}{ccccc}
\hline Model & $\mathrm{R}$ & R Square & $\begin{array}{c}\text { Adjusted R } \\
\text { Square }\end{array}$ & $\begin{array}{l}\text { Std. Error of } \\
\text { the Estimate }\end{array}$ \\
\hline 1 &, $815^{\text {a }}$ &, 664 &, 634 & 1,245 \\
\hline a. & Predictors: (Constant), Total_X4, Total_X2, \\
& Total_X1, Total_X3 \\
b. & Dependent Variable: TOTAL_Y
\end{tabular}

Berdasarkan tabel 2 hasil analisis menunjukkan bahwa nilai koefisien determinasi (Adjusted $R$ Square) sebesar 0,634 atau 63,4\%. Hal ini dapat menjelaskan bahwa 63,4\% perubahan variabel terikat yaitu keputusan pembelian (Y) dipengaruhi oleh perubahan variabel bebas yaitu kualitas produk (X1), harga (X2), kualitas layanan (X3), lokasi (X4) sedangkan sisanya yaitu 36,6\% (100\%-63,4\%) dipengaruhi oleh variabel terikat lain tidak termasuk pada penelitian ini.

Perhitungan koefisien korelasi $\left(\mathrm{R}^{2}\right)$ digunakan untuk mengukur tingkat kekuatan hubungan antara variabel bebas dengan variabel terikat. Nilai $R$ yaitu sebesar 0,815 . Apabila nilai koefisien mendekati 1 maka semakin tinggi koefisien variabel bebas kualitas produk (X1), harga (X2), kualitas layanan (X3) dan lokasi (X4) terhadap variabel terikat keputusan pembelian (Y). Hal ini menunjukkan bahwa hubungan antara variabel bebas terhadap variavel terikat dikategorikan sangat kuat.

\subsection{Uji F}

Bertujuan untuk menguji pengaruh variabel bebas yaitu kualitas produk (X1), harga (X2), kualitas layanan (X3) dan lokasi (X4) secara serempak berpengaruh signifikan terhadap variabel terikat yaitu keputusan pembelian (Y) pada konsumen di warung ikan bakar Bu Tatik .

Table 3. Hasil Uji F

\begin{tabular}{|c|c|c|c|c|c|}
\hline \multicolumn{6}{|c|}{ ANOVA $^{\mathrm{a}}$} \\
\hline Model & $\begin{array}{l}\text { Sum of } \\
\text { Squares }\end{array}$ & Df & $\begin{array}{c}\text { Mean } \\
\text { Square }\end{array}$ & $\mathrm{F}$ & Sig. \\
\hline Regression & 137,943 & 4 & 34,486 & 22,253 &, $000^{\mathrm{b}}$ \\
\hline $1 \underline{\text { Residual }}$ & 69,737 & 45 & 1,550 & & \\
\hline Total & 207,680 & 49 & & & \\
\hline \multicolumn{6}{|c|}{ a. Dependent Variable: Total_Y } \\
\hline $\begin{array}{l}\text { b. Predictors: (C } \\
\text { Total_X3 }\end{array}$ & astant), Total & $\mathrm{X} 4$, & tal_X2, & otal_X1, & \\
\hline
\end{tabular}

Berdasarkan tabel 3 hasil uji $\mathrm{F}$ dengan menggunakan alat bantu program SPSS 21.00 for windows diperoleh nilai signifikan sebesar $0,000^{\mathrm{b}}$ menunjukkan bahwa nilai signifikan $<$ taraf signifikan $(\alpha=0,05)$ hipotesis diterima. Hal ini dinyatakan bahwa variabel kualitas produk (X1), harga (X2), kualitas layanan (X3) dan lokasi (X4) secara serempak berpengaruh signifikan terhadap variabel keputusan pembelian (Y) di warung ikan bakar Bu Tatik Kabupaten Situbondo.

\subsection{Uji t}

Digunakan untuk membuktikan signifikan atau tidaknya pengaruh variabel bebas yaitu 
kualitas produk (X1), harga (X2), kualitas layanan (X3) dan lokasi (X4) secara parsial berpengaruh signifikan terhadap variabel terikat yaitu keputusan pembelian (Y) di warung ikan bakar $\mathrm{Bu}$ Tatik Kabupaten Situbondo. Berdasarkan data pada tabel 1 hasil analisis regresi linear berganda menggunakan alat bantu program SPSS 21.00 for windows diketahui bahwa:

a. Variabel Kualitas Produk (X1), variabel ini memiliki nilai signifikan sebesar 0,003 . Menandakan jika nilai signifikan uji t lebih kecil dari taraf signifikan $0,05(0,003<0,05)$. Dapat disimpulkan bahwa secara parsial variabel kualitas produk (X1) berpengaruh signifikan terhadap variabel keputusan pembelian (Y), maka hipotesis diterima.

b. Variabel Harga (X2), memiliki nilai signifikan sebesar 0,041. Menandakan jika nilai signifikan uji t lebih kecil dari taraf signifikan $0,05 \quad(0,041<0,05)$. Dapat disimpulkan bahwa secara parsial variabel harga (X2) berpengaruh signifikan terhadap variabel keputusan pembelian (Y), maka hipotesis diterima.

c. Variabel Kualitas Layanan (X3), variabel ini memiliki nilai signifikan sebesar 0,008. Menandakan jika nilai signifikan uji t lebih kecil dari taraf signifikan $0,05(0,008<0,05)$. Dapat disimpulkan bahwa secara parsial variabel kualitas layanan (X3) berpengaruh signifikan terhadap variabel keputusan pembelian (Y), maka hipotesis diterima.

d. Variabel Lokasi (X4), memiliki nilai signifikan sebesar 0,034. Menandakan jika nilai signifikan uji $\mathrm{t}$ lebih kecil dari taraf signifikan $0,05 \quad(0,034<0,05)$. Dapat disimpulkan bahwa secara parsial variabel lokasi (X4) berpengaruh signifikan terhadap variabel keputusan pembelian (Y), maka hipotesis diterima.

Secara keseluruhan hasil analisis menunjukkan bahwa pengaruh variabel kualitas produk, harga, kualitas layanan dan lokasi secara serempak berpengaruh signifikan tehadap keputusan pembelian di warung ikan bakar Bu Tatik Kabupaten Situbondo. Hal tersebut terjadi dikarenakan warung ikan bakar Bu Tatik selalu mengandalkan rasa yang tetap sama, harga yang sesuai dengan kualitas produk, pelayanan yang diterapkan sangat memuaskan konsumen dan mudahnya lokasi yang dijangkau konsumen mengakibatkan konsumen cenderung untuk melakukan keputusan pembelian atau pembelian kembali. Berdasarkan hasil analisis data yang dilakukan, diketahui variabel yang berpengaruh dominan terhadap keputusan pembelian warung ikan bakar Bu Tatik di Kabupaten Situbondo adalah kualitas produk (X1). Karena variabel kualitas produk (X1) memiliki nilai uji t paling besar diantara variabel lainnya yaitu sebesar 3,161 dan nilai signifikan paling kecil sebesar $0,003(0,003<0,05)$. Karena konsumen beranggapan bahwa kualitas produkyang diberikan oleh warung ikan bakar Bu Tatik Kabupaten Situbondo ini memiliki tingkat kualitas bahan baku yang baik mulai dari ikan yang masih segar dan cita rasa warung ikan bakar $\mathrm{Bu}$ Tatik memiliki yang tidak pernah berubah.

\section{Kesimpulan}

Berdasarkan hasil analisis dan pembahasan yang diperoleh dari penelitian di warung ikan bakar $\mathrm{Bu}$ tatik Kabupaten Situbondo disimpulkan bahwa variabel kualitas produk, harga, kualitas layanan dan lokasi secara serempak berpengaruh signifikan terhadap keputusan pembelian, serta seluruh variabel bebas secara parsial berpengaruh signifikan terhadap variabel terikat. Sehingga menghasilkan varibel kualitas produk yang memiliki pengaruh dominan terhadap keputusan pembelian.

\section{Daftar Pustaka}

[1] Sopiah dan Sangadji. 2013. "Perilaku Konsumen Pendekatan Praktis Disertai Himpinan Jurnal Penelitian", Yogyakarta: Andi Yogyakarta.

[2] Herlambang, S. 2014. "Basic Marketing (Dasar Dasar Pemasaran) Cara Mudah Memahami Ilmu Pemasaran. Yogyakarta: Gyosen Publishing. 